$\mathrm{K}$.

Osvobozhdeniye

golosa.

Retrieved

from

http://school4you.ru/download/orator(2)/\%D0\%9B\%D0\%B8\%D0\%BD\%D0\%BA\%D0\%BB\%D1\%8D\%D0\%B9\%D1\%82\% D0\%B5\%D1\%80\%20\%D0\%9A.\%20-

\%20\%D0\%9E\%D0\%A1\%D0\%92\%D0\%9E\%D0\%91\%D0\%9E\%D0\%96\%D0\%94\%D0\%95\%D0\%9D\%D0\%98\%D0\%95\% 20\%D0\%93\%D0\%9E\%D0\%9B\%D0\%9E\%D0\%A1\%D0\%90\%20-\%201.pdf.

7. Stulov, I.Kh. (2013). Nekotoryye osobennosti raboty s golosami estradnykh pevtsov. Sbornik nauchnometodicheskikh statey kaf. peniya i khorovogo dirizhirovaniya MPGU, 2, 58 - 62 [In Russian].

8. Romanova, L.V. (2007). Shkola estradnogo vokala. Saint-Petersburg, Lan [In Russian].

9. Yakusheva, O.R. (2008). K voprosu o spetsifike estradnogo peniya. Vestnik Kostromskogo gosudarstvennogo universiteta, 2, 72-74 [In Russian]

Стаття надійшла до редакції 06.10.2018 p.

UDC: $78.071 .1(092)(73)^{\prime 19 "}$

Boychuk Iryna

Ph.D in Psychological Sciences,

Associate Professor of Music Department,

Chernivtsi National University

named after Yuri Fedkovych

ORCID 0000-0001-6702-9121

iraboychuk7@gmail.com

Herehova Svitlana

Ph. D in Historical Sciences,

Associate Professor of the Department of

History of Ukraine,

Chernivtsi National University

named after Yuri Fedkovych

ORCID 0000-0001-7906-475X

s.geregova@chnu.edu.ua

\title{
UKRAINIAN SOURCES OF CREATIVE WORK OF HOLLYWOOD COMPOSER HAMMA SKUPYNSKYI
}

The purpose of the research is to investigate the contribution of $\mathrm{H}$. Skupynsky in Ukrainian and world music and to identify and to eliminate gaps in the study of life and creative activity of the Hollywood composer. Methodology. Methods of historiographical, biographical, comparative and contextual analysis have been applied. In particular, the biographical method allowed revealing and eliminating the gaps in the life and creativity of $\mathrm{H}$. Skupynsky in Ukraine (in Bukovina) and helped to follow the change of the artist's creative orientation after his move to the United States. The historiographical method was used for the analysis of the social and cultural significance of the composer's work in his homeland and in emigration, and the comparative and contextual method helped to conclude the research results in the panorama of the historical, cultural and musicological portrait of $\mathrm{H}$. Skupynsky. Scientific novelty consists in the fact that this research reveals the unknown historycal pages of the formation of such legendary musical groups as "Chervona Ruta" and "Smerichka", shows the role of H. Skupynsky in this process and for the first time describes his work, based on the Ukrainian national specific of the Bukovinian musical motifs. Conclusions. The analysis of the special literature reveals the importance of comprehension of the figure of Hamma Skupynskyi in the processes of hidden cultural development of art and music during the Soviet period. As music art need to be realized through a recipient and cannot exist by itself, as for example literature, Hamma Skupynskyi became famous abroad, in Canada and USA, being Ukrainian in his heart, a soul-mate with the Ukrainian composers of the "continent Ukraine". Creation of the world of "Ukrainianity" is a significant factor for the implementation of foreign relationships of Ukraine, providing a positive international mutual influence and developing economic and cultural potential.

Keywords: Hamma Skupynskyi; Soviet period; Ukrainian music history; cultural impact; social development of music art; music in XX century.

Бойчук Ірина Ігорівна, кандидат психологічних наук, доцент кафедри музики Чернівецького національного університету імені Юрія Федьковича; Герегова Світлана Володимирівна, кандидат історичних наук, доцент кафредри історії України Чернівецького національного університету імені Юрія Федьковича

Українські джерела творчості голлівудського композитора Гамми Скупинського

Мета роботи. Дослідити внесок Г. Скупинського в українську та світову музичну культуру, виявити та усунути прогалини в дослідженні життєвого шляху та творчої діяльності голлівудського композитора. Методологія. Застосовані методи історіографічного, біографрічного, порівняльного та контекстуального аналізу. Зокрема, біографічний метод дозволив виявити та усунути прогалини у життєвому та творчому шляху Г. Скупинського в Україні (на Буковині), прослідкувати зміну творчих орієнтирів митця після його переїзду до США. Історіографрічний метод прислужився в аналізі суспільного та культурного значення творчості композитора на батьківщині та в еміграції, а порівняльний і контекстуальний методи допомогли укласти результати дослідження у панораму історико-

(C) Boychuk I., 2018

(C) Herehova S., 2018 
культурного й музикознавчого портрету Г. Скупинського. Наукова новизна. Дослідження розкриває невідомі сторінки історії становлення легендарних музичних колективів "Червона Рута", "Смерічка", показує роль Г. Скупинського у цьому процесі, вперше описується його творчість, основану на українському національному колориті буковинських музичних мотивів. Висновки. Аналіз наявної літератури у вигляді спогадів, окремих наукових розвідок та документальних даних, матеріалів у місцевій пресі показує важливість розуміння фрігури Гамми Скупинського в процесах прихованого культурного розвитку мистецтва та музики в радянський період. Оскільки музичне мистецтво потребує реалізації в реципієнта й не може функціонувати саме у собі, як, скажімо, література, Гамма Скупинський став відомим за кордоном, у Канаді та США, будучи українцем в душі, однодумцем з українськими композиторами «материкової України». Створення «світу українства» $\epsilon$ важливим фрактором для реалізації зовнішніх відносин України, що забезпечує позитивний міжнародний взаємовплив, розвиваючи економічний та культурний потенціал.

Ключові слова: Гамма Скупинський; радянський період; історія української музики; культурний вплив; соціальний розвиток музичного мистецтва; музика в XX столітті.

Бойчук Ирина Игоревна, кандидат психологических наук, доцент кафедры музыки Черновицкого национального университета имени Юрия Федьковича; Герегова Светлана Владимировна, кандидат исторических наук, доцент кафредры истории Украины Черновицкого национального университета имени Юрия Федьковича

Украинские истоки творчества голливудского композитора Гаммы Скупинского

Цель работы. Исследовать вклад Г. Скупинского в украинскую и мировую музыкальную культуру, выявить и устранить пробелы в исследовании жизненного пути и творческой деятельности голливудского композитора. Методология. Применены методы историографического, биографического, сравнительного и контекстуального анализа. В частности, биографический метод позволил выявить и устранить пробелы в жизненном и творческом пути Г. Скупинского в Украине (на Буковине), проследить смену творческих ориентиров художника после его переезда в США. Историографический метод послужил анализу общественного и культурного значения творчества композитора на родине и в эмиграции, а сравнительный и контекстуальный метод помогли заключить результаты исследования в панораму историко-культурного и музыковедческого портрета Г. Скупинского. Научная новизна. Исследование раскрывает неизвестные страницы истории становления легендарных музыкальных коллективов "Червона Рута", "Смеричка", показывает роль Г. Скупинского в этом процессе, впервые описывая его творчество, основанное на украинском национальном колорите буковинских музыкальных мотивов. Выводы. Анализ литературы в виде воспоминаний, отдельных научных исследований и документальных данных, материалов в местной прессе демонстрирует важность понимания фригуры Гаммы Скупинского в процессах скрытого культурного развития искусства и музыки Буковины. Поскольку музыкальное искусство требует реализации у реципиента и не может функционировать само в себе, как, скажем, литература, Гамма Скупинский стал известным за рубежом, в Канаде и США, будучи украинцем в душе, единомышленником украинских композиторов «материковой Украины». Создание «мира украинства» является важным фрактором для реализации внешних отношений Украины, что обеспечивает положительное международное взаимовлияние, развитие экономического и культурного потенциалов.

Ключевые слова: Гамма Скупинськийж советский периодж история украинской музыкиж культурное влияниеж социальное развитие музыкального искусстваж музыка в XX веке.

Introduction. Ukrainian national culture has passed a complicated way, having absorbed the best heritage of the past, having been enriched the cultures of other nations, and having enriched the world culture. There were a lot of achievements and losses on this way. The historical memory of Ukrainian nation recovers today, its wealth cultural heritage returns, as well as excluded pages of the history, names of Ukrainian cultural leaders. Certainly, independent Ukraine needs the whole epoch of «restoration» and activity in this direction of the significant cohort of scientists, in order to reanimate semi-withered source of national culture in the time of the Soviet totalitarian regime. Efficiently new stage of development of historical science has started after proclamation of the independence of Ukraine, that was marked by eradicative rethinking of historical concepts, deprivation of some stereotypes, new interpretation of historical facts, investigation of silenced or little-known events of the past, return of the names of forgotten representatives of national culture, etc.

It is necessary to note, that exactly intelligentsia played and remains to play one of the most important roles in the economic, political and spiritual life of society. Official ideology assigned the second place for intelligentsia in the totalitarian Soviet state, however, enough attention was paid for it, when it was necessary to find "guilty» in its far not ideal policy, attaching offensive labels on the best leaders of Ukraine. The conflict between the freedom of creativity of a personality and needs of socially-political system inevitably arises in the totalitarian society. This conflict is solved very simply: the personality starts to create in accordance with ideological instructions of the system, or it destroys the personality as an artist, and in the predominant majority physically, or in another way, the personalities leaves the native land in order to protect their creativity and life from excessive censorship, and they naturally and freely create in conditions of freedom, however in the surrounding of alien ethnic environment and cultures, for the benefit of the other nations. Relevance of the research topic. The figure of Hamma Skupynskyi is very interesting for investigation in this context; he is a composer with world name, doctor of musician art of Boston University, who started his working activity above forty years ago in song capital of Bukovynian region, in Chernivtsi city; his livelihoods stays practically not investigated nowadays. What made the men who achieved significant success in his working activity to leave native land? Or is it simply set of circumstances? 
For the answer on this question it is necessary to appeal to the period of formation of creative interests of Hamma Skupynskyi and his attitude as a musician, composer, that occurred in conditions of totalitarian Soviet society.

Historical basis of the research. Euphoria of the victory in the war changed to the pain of disappointment from repressions from the side of Stalin regime for the population in postwar period. Since 1948, the next wave of repressions was widespread on Jewish intelligentsia near with Ukrainian one, which was blamed in Zionism, cosmopolitism, «crawling» to capitalist West, bourgeois lifestyle, etc. In winter of 19481949, the Jewish state theaters were closed in the USSR; prominent actor and director Solomon Mihoels (Vovsi) was died in 1948 at enigmatic circumstances in Mink. 24 leaders of Jewish culture were arrested and executed, 18 of them were from Ukraine. There was the founder of Jewish Soviet poetry Davyd Hofshtein, who is the author of many translations from Shevchenko, Franko, L. Ukrayinka, Rylskyi, Sosiura, as well as Irma Druker, Note Lurie, Moisei Altman.

It is necessary to note, that creative artistic intelligentsia brightly showed itself after the death of $Y$. Stalin and de-Stalinization processes, which started to be implemented after the XX Congress of CPSU (1956), outlook of which was formed under the impact of cardinal socio-political changes of that time. The young generation of innovators entered into the cultural life of the country, that accepted changes and rethinking of the values, as an appeal to new forms and means of the art reflection. This new generation of artists entered into the history with the name «sixtiers» that derives from the chronological period of their activity. Statement of basic materials. The problem of art, relations between the writer and authority, the right of the artists on their opinion and style were the central problems of spiritual life in the period of «thawing»: the government didn't want to cope with searching of new literary-artistic forms, distinctive from "petrified masks» of socialistic realism, that took place at the initial period of the sixtiers.

Although, the part of creative intelligentsia perceived criticism of the cult of personality of Stalin and de-Stalinization with caution, considering it as the regular provocation of the government, however, some of them identified these tendencies with the beginning of building democratic society, where every citizen has the right to freely express their thoughts and convictions.

However, in the spring of 1959, 11 thousands of people were still kept in camps and colonies of the USSR, who were imprisoned for counter-revolutionary crimes. It was a small number comparing to the 949 thousand political prisoners of the Gulag in spring 1954; at the beginning of the 60s, Hrushchov declared that there are not political prisoners in the country. In addition, nonconforming movement deployed at the same time, that gave new prisoners, as it is known $[8,108]$. As the authority had not the power to prohibit the people to express their opinion in occasion of existing life problems, that refused from extreme forms of terror.

The new wave of Ukrainian nationally-cultural revival had started, that was properly headed by the sixtiers. The Clubs of creative youth were founded, at their meetings artistic problems and tasks were discussed; sections were working, whose activity was directed into the development of creative potential of the young artists, exhibitions of the works were established, as well as literature evenings, where new works were discussed, as well as new directions of creative activity, one of which was the honoring the best representatives of national culture, in particular, L.Ukrayinka, I. Franko, T. Shevchenko, etc.

In addition, the second part of the 50s was marked by the expansion of the contacts of the Soviet society with the external world. Western singers, theater actors, jazz bands, exhibitions of the clothing models went to the USSR on tour.

The shows of «alien» fashion were officially allowed in the hall of GUM and on the pages of an international magazine; modern western music resounded everywhere. It emancipated the Soviet youth. Fashionable haircuts, clothes, music, lifestyle, became the objects of its alert attention.

The international festival of youth and students implemented a great impact on the youth, that took place in Moscow. The Soviet youth could freely communicate with foreign yearlings for the first time in many years. According to the words of contemporary of the festival V. Skurativskyi, «not the victory of "socialism forces" became the result of Moscow festival, but the mutual introduction of free West and the Soviet Union that escaped from the ties of Stalinism at that time» $[3,44]$.

However, the revival of nationally-cultural traditions and outcome of intelligentsia outside the established frames of art were not included in the authority's plans. Official ideology tried to prove historical communion of the two nations, which are Ukrainian and Russian ones in this period, leveling any differences in their development, on the contrary, reducing the role of national cultures.

Liberalization of society was conducted inconsistently, a significant part of the facts about repressions of last years remained unknown for society, which in its turn demanded more information, being raging by the decision of the Congress. Ideological engagements gained statement about the solution of a national problem in the USSR. The scientific grounding of the single common Soviet nation was implemented in the background of the revelry of Russian chauvinism, invasive Russification of national republics, artificial narrowing of the spheres of consumption of national languages, ignoring of multi-centuries traditions of nations, which entered the compound of the Soviet Union $[5,17]$.

In addition, the authority used to unprecedented actions namely arrests if intelligentsia for its freethinking, especially in relation to the authority, shortly after proclamation of the course into liberalization. Legislative and normative bases also promoted it, which largely expanded possibilities of overbearing structures 
in the implementation of political repressions, by the way, it contradicted the constitutional principles concerning providing of the rights and freedoms of the USSR citizen. So, the law of the USSR was approved from December, 25, 1958 "About criminal responsibility for state crimes", the notorious article "Anti-Soviet agitation and propaganda (p. $62 \mathrm{KK} \mathrm{SSR}$ ) was introduced into criminal codes, numerous instructions and recommendations of the KGB at the Ministers Council at the USSR, the General Prosecutor of the USSR, the Supreme Court of the USSR, their jurisdictional authorities [2, 472]. These peculiarities took place in normative basis even later. As R. Conquest mentioned, «the system of political management of the USSR has not qualitatively changed or the basic principles that stay behind this system» $[7,351]$. The «thawing» of Hrushchov couldn't destroy characteristic ideologization of all sides of the life, including the culture, such phenomena as monopoly in social life, full intolerance to dissidents, destruction of historical memory and others, which were inherent to Stalinism were not outdone. This meant, that official structures were unable to refuse from ideological dogmas of Stalinism.

There were not cardinal changes in the political system of the USSR, despite all positive upheavals in the country in the period of "thawing». The Soviet Union has not become the legal state, in return, the transformation happened from the totalitarian to the authoritarianism. So, the existing political system stayed one-party, election into the public authorities was non-alternative, the ability to display of the initiative of masses was absent in the management of state deals.

The resolution of CC CPSU from January 7, 1969, «About the increasing of responsibility of managers of press, radio, television, cinematography, institutions of culture and art for ideological-political level of material, that are published and repertoire» can be assumed as apogee in connection with severe censorship (the Resolution of CC CPU about the strengthening of censorship immediately became the answer) ${ }^{6}$, as well as restriction of access to official translators of the creation of progressive artists into society; they found the other way of spreading their works, namely samizdat, that is the world phenomenon by its scale and universal by its purpose. It lies at the intersection of literature, linguistics, history, psychology, social science, political studies, cultural studies, art studies, etc.

Its main task consisted in the distribution of objective information about concealed processes and events in Ukrainian public and cultural life of the nation. So, in the period from 1965-1972, even publications with the advantage of journalism appeared where the attempt was made to analyze acute problems of social life from Marxist-Lenin position: historical, human rights, social-political problems of the Ukrainian nation and the state of public liberty in the USSR. A lot of them were with authorial signatures. Do people stop to be afraid of the authority? The words of the participant of samizdat and rights defender L. Alieksieieva can be the answer on this question: «People who got hungry for truthful picture of the world and unsophisticated knowledge were agreeable to sacrifice their time, work and even suffer from persecution for the sake of these benefits» [7, 351]. At the same time, the fear for the life of relatives and close friends remained a predominant factor of social behavior of the population.

There are no doubts, that the formation of the new generation of the artists was occurred under the impact of aforementioned events not only in literature but in fine and musical art in the USSR and in Ukraine in particular. Talented musician Hamma Skupynskyi (11.02.1946) was in their number. He charged everybody around by his creative drive of versatile creative novelties, which were connected with the best achievements of the world musical culture and respect to Ukrainian song that found the reflection in his activity in the vocalic-instrumental ensemble "Smerichka" (1974).

During the education at Kazan conservatory, the composer wrote the range of songs on the words of Konstiantyn Lopushanskyi, who is now prominent film-maker from St. Petersburg, and at that time he was Hamma's friend. Oleksandr Bronevytskyi and Edita Pieha liked one song and they included it in the repertoire of the concert program. Several songs appeared later, which had significant success that can be considered as trial by fire for $\mathrm{H}$. Skupynskyi as a composer-songwriter.

"The first symphony" for stringed, percussion instruments and the electro-pipe organ was performed simultaneously at the state exam from the composition. H. Skupynskyi mentioned: "Karavella" with guitars, drums, microphones came out after the performance and "played" several songs. Such "political intrigue" has not occurred in the walls of conservatory yet! The boys recollect and talk till today: "Do you remember...?" - "But looking back, I can say that all this was the beginning of the future!".

A lot of pedagogues took prominent positions later, who were recollected by the composer. So, Albert Leman was the head of the department of composition at Moscow conservatory (1971-1997). Bernard Rans became the president of the department of composition at Harvard University. Robert Syrota was the president of Manhattan School of Music (2005-2013). According to the doctor Skupynskyi, he got a big luck with teachers.

He had started pedagogical activity at Chernivtsi musical college after graduation from Kazan conservatory, teaching the Theory of music, Sol-fa, and Harmony. Pavlo Dvorskyi and Viktor Rurak were among students of $\mathrm{H}$. Skupynskyi. They recollected their teacher with appreciation, focusing attention on the diversity of his talent as a composer, arranger, pianist, performer.

Pavlo Dvorskyi indicates: "...he was not such like everyone, he never imposed his opinion, gave the possibility to improvise, contribute something new, interesting. The lessons of Sol-fa are especially remembered. He gave musical dictations different for each student, considering musical abilities of everyone, he 
gave the possibility of creative growth for the talented ones. He often conducted small competitions among the students, even gave the presents. As he was a subtle nature, he always found something, trying to make holiday from each moment - musical, human and always with humor. Everyone who had been in his company felt that he wanted to do something new".

Pavlo Dvorskyi continues: "I remember when he gave me a very interesting dictation, I recollect that I had written it very well (although more than three decades have passed) and Hamma Skupynskyi told me then: "Pavlyk, you have good abilities, you will be able to write your own music". I have already tried to write my own songs at that time, but when a prominent teacher and composer tells it to you I have thought..., maybe it is true... These wished have been said in a good time, in a good hour and I started to write music".

The composer successfully conducted the amateur performance at the university and simultaneously taught musical-theoretical disciplines at Sydor Vorobkevych musical college, combining the work in Chernivtsi Philharmonic.

The composer wrote accompaniments for popular Ukrainian and Russian songs of that time and prepared the artists for the concert performances, teaching the students to sing and play on musical instruments. The students of historical and philological faculties of Yurii Fedkovych Chernivtsi national university took part in the vocalic-instrumental ensemble. A lot of internal university events were conducted where the talented youth could show musical abilities. As Hamma Skupynskyi recollects, one talented student of the philological faculty was the author of the text of anti-war rock-opera - «E=(MC)2», and participants of the rock band were also performers of the composition.

Vocalic-instrumental ensemble took part at the Third festival of rock music of youthful and political song (March 15-18, 1973) that took place in Petrozavodsk; they won the First place for the best authorial song there "Oi teche voda» [Oh the water flows]. There is an interesting fact, that this song was successfully performed after over 40 years at the authorial concert of the doctor Hamma Skupynskyi - «Bukovynian patterns» (29.11.2006 in Chernivtsi city) by the sisters Yuliia and Viktoriia Bilinska, who were the students of the music department from Yurii Fedkovych Chernivtsi national university.

Pinkus Abramovych Falik (former director of the Philharmonic) invited Hamma Skupynskyi to Chernivtsi Philharmonic for working with a prominent group "Smerichka ", in parallel with pedagogical work.

As the proposal was very interesting, Hamma Skupynskyi started the work with the preparation of the group's program. He was always interested in technical musical novelties, that's why the unique collection of synthesizers, various equipment of that time was picked up in the composer, which had been used during the recording of the discs of "Chervona Ruta" and "Smerichka".

Musical culture of Bukovyna region was always developing enriching by the cultures of different nationalities, which historically live there - Ukrainians, Romanians, Germans, Poles, Czechs, Hungarians, Russians and representatives of the other nationalities. Obviously, this fact found its reflection in musical art of the region.

According to the opinion of the doctor Skupynskyi - "All ethnic intonations are interlaced and reanimated the music of Bukovyna (hutsuls in particular) the music that lives in my heart, too. That's why creating the first program for the group "Chervona Ruta", I refused from Middle-Ukrainian repertoire ("Ty zh mene pidmanula", "Oi ty divchyno z horiha zernia" and others"), I appealed only to local, Bukovynian repertoire. It helped to create the group with unique coloration, that had not existed before till that time in popular youthful music. The accession of Sofiia Rotaru to the group with her multi-lingual repertoire strengthened this general progressive tendency of stylistics of Bukovynian song".

The composer was interested in progressive songs directions of that time during the work at Philharmonic, that could not be marked on the work with the original vocalic-instrumental group "Smerichka".

The maestro recollected, that such bands as "Chicago", "Krov, Pit i Sliozy", "Bich Boys" made a great popularity. Also, the ensemble performed songs in style of Italian-French chanson of Valeriy Hromtsev, who was the composer and conductor of "The Carpathians" ensemble.

With regard to the ensemble "Smerichka", doctor Skupynskyi notes: "As the music of the ensemble was bright and original, I continued this tradition in such songs as "Oi chyia zh to krainia hatka", "Ty", "Skrypka". I proposed the new decision in arrangement of songs, using the styles close by the character to the music of the 70s: "Blues Grass", "Jazz-Rock", "Disco", "Prog-Rock" and others popular songs forms. I think, it also helped to worthily represent Bukovynian song at the international arena of Sopot festival with the victory performance of Sofiia Rotaru (1974).

During the years of creative cooperation with "Chervona Ruta" and "Smerichka" ensembles, the artist could evict the groups to the heights of popularity, due to innovations in instrumentation and composition, where he combined rock, folklore, and jazz. The criticism had started, as those time were characterized by the prohibition of something new, progressive.

However, discovery and popularization of such great talents as Volodymyr Ivasiuk, Vasul Zinkevych, Sofiia Rotaru, Nazarii Yaremchuk, famous group "Smerichka" headed by Levko Dudkivskyi were their merit. Indeed, Chernivtsi region flashed with the cluster of prominent artists and performers, charmed Ukraine and the world with unfamiliar melodic and at the same time modern songs. Native Carpathians landscapes and melodies inspired the creativity of outstanding actor and director Ivan Mykolaichuk. 
Hamma Skupynskyi collected and the processed large amount of songs from different corners of Bukovyna. Talented master instrumented them and gave new breathing, in particular, to Bukovynian national song "Oi chyia zh to krainia hatka", where the author implemented interesting compositional decisions and was able to convey the main idea of the composition. Such song as "You - the sun in the sky" was considered as national one, it was chanted by everyone at the meeting, concerts, and not only in Ukraine, but in Moldova and Russia.

The songs of Hamma Skupynskyi were very popular not only in concert implementation but were recorded by the "Melodiia" firm (the only sound recording firm in the USSR). In addition, Skupynskyi was recommended by the professor from Moscow conservatory Albert Semenovych Leman for acceptance to the members of the composers of RFSR.

By the events of the 70s, as doctor Skupynskyi recollects: "The concert of the festival in Munich was showed on television, where Sofiia Rotaru performed the song of Hamma Skupynskyi "Liubov", for what she was rewarded with the Second premium.

In 1971, Hamma Skupynskyi wrote "Bukovynska rapsodiia" [Bukovynian rhapsody] for professional woodwind orchestra of the headquarter of Prykarpattia military county (CMD) from Lviv city. The woodwind orchestra successfully performed the Rhapsody not only for the lovers of woodwind music but opened the concert program with it at tours in many cities of Western Ukraine. In 1973, the orchestra of the headquarter CMD deservedly assigned the First place for performing "Bukovynska rapsodiia" at the Second International competition-festival of woodwind orchestras in Yugoslavia.

In the same period (1971-1972), formulation of anti-war rock-opera - "E $=(M C)^{2 n}$ occurred in Chernivtsi. The story of the opera is dedicated to the destiny of the American pilot "Enola Gay" who threw the first atomic bomb on Hiroshima.

For a certain time, Hamma dreamt about the setting of the opera on the big stage with the participation of professional musicians. At that time, students and teachers of musical college were the performers, as well as participants of rock-band form the university and local musicians (Ahashkin, Fima Shehter, Marik Kushnir and others). As Hamma Skupynskyi taught at musical college at that time, the consignments were studied at the lessons of Sol-fa and after the lessons with choir students.

As the participants of rock-opera recollect, it was extremely interesting at the rehearsals, especially musical instrumental decisions of the composer impressed, high awareness of Hamma with the world musical literature and the work of national musical art of the region was felt. The composer assigned scores for all instruments, including woodwind ones. The rehearsals were stared at eight-nine o'clock in the evening and were continued almost till midnight.

The question occurred in a short time: where will the rock-opera be performed? Some of the friends proposed the House of textile workers. At the time, the preparation for October festivals was conducted and the majority of performers was involved in the House of officers. As recollects Hamma, together with his participants, he decided to organize the premiere of the rock-opera in the neighboring House of textile workers. However, the rehearsal was delayed to 11 PM, so it had been already 2-3 AM when all people gathered and the equipment was switched on. Despite the late hour, about a hundred of people gathered at the concert of rock-opera.

Here is how the setting of rock-opera occurred in Chernivtsi! It was the setting of the first rock-opera in the Soviet Union. As the composer witnesses, the rock-opera "E $=(M C)^{2 n}$ was written and set within three years, earlier than rock-opera "Orpheus and Eurydice" by Zhurbin in Leningrad (1975).

The next disc-giant was released in Sofiia Rotatu, where the song "Doroha" [The Road] was, that was written by the composer Hamma Skupynskyi on the words of Kyiv poet Borys Kasiiev, during the artist's stay in Italy.

In 1979, Hamma Skupynskyi emigrated to the USA. He was one of those people, who was forced to leave the homeland, not agreeing with the situation about the development of original and at the same time innovative culture in the state. The report note about some questions of strengthening of struggle with the anti-Soviet Zionist propaganda of prevention emigrant attitudes among the separate part of the Jewish population of the Republic written by the secretary of CC of the Communist Party of Ukraine O.S. Kapta from September 28, 1979, with the stamp «Extremely secret» [6].

Emigrating to the USA, H. Skupynskyi entered the composer faculty of Boston New England Conservatory. Graduating Master program in the class of Malcolm Peyton (composition) and George Russel (jazz), he continued his education at Boston University. The maestro visited the classes of the most interesting musical leaders there, such as Pierre Boulez, John Cage, Gyorgy Ligeti, John Adams, Steve Reich and many other prominent composers of that time.

Living in Boston, Hamma Skupynskyi was engaged in the theory of modern media-art and the problems of artificial mind in "MediaLab" at Massachusetts technology institute within several years. He wrote compositions for municipal holidays on order of the Committee of the art in Boston city from 1987 to 1992. The setting of ballet "Holodylnkyk" [Refrigerator] occurred there, as well as rock-opera "Mizky Hrafiti" [Brains Grafitti]. 
Having defended the dissertation at Boston University and received the title of doctor of musical art from the composition, Hamma moved to Los Angeles, for the work in a film studio in Hollywood. And at the same questions: "Where are you from?" -he answered with pride - "I am from Chernivtsi!".

It is detected, that Chernivtsi city is known on the West for a long time, as the character form the novel stays to spend the night in Chernivtsi in the popular novel of Bram Stocker "Dracula»! As the composer notes: "My stylistics of musical language was connected with "Transylvanian (vampire)" accent because of it. The string quartet "Pisni vampiriv" [The songs of vampires] occurred, that was dedicated to the film actor Bela Lugosi, who had been the best performer of the role of Dracula...

A very strange story happened with this music later. In 1996, Hollywood celebrated the $50^{\text {th }}$ anniversary of the day of the death of Bela Lugosi and it was decided to perform the string quartet. Before the concert in Los Angeles, "secret stranger" appeared with the collection of instruments of Stradivarius, Guarneri and asked the performers to play on these instruments. Such collection of bows must be seen! Musicians were captured by this idea. Musical act was happened, despite everything, and string quartet was played with great success. The collector gathered the instruments and disappeared, not naming. It is still a mystery, how did the stranger know that this quartet would be performed?

The composer had established Post-production studio "Gamma Soundworks" in Hollywood and started to cooperate with such famous American film studios as Sony Pictures, Kushner-Lok, New Wave and with independent filmmakers.

He created the soundtracks to 35 films with the participation of the actor Jackie Chan. In 2000, the film "Criminals" with the music of Hamma Skupynskyi (the director of the film is Jeff Butcher) got into the top ten best independent films of that year. Musical compositions of Hamma were published in the press, recorded on the studios, performed on the radio and on the concerts in Russia, America, and Europe. Except popular songs and jazz compositions, the achievement of Hamma Skupynskyi contains twelve symphonies, three ballets, more than ten operas, seven string quartets, concerts for different instruments, infant miniatures, chamber forms, audiovisual installations and music for cinema and theater.

Conclusions. Investigating the personality of Hamma Skupynskyi, extraordinary diversity of his creative thinking can be noted. The artistic heritage of the maestro contains various images - lyrical, dramatic, sad, cheerful, playful. H. Skupynskyi contributes a lot of new, experimental to the creation, consonant with his individuality. Hamma Skupynskyi always dreamt to be a musician, wanted to be on the top of events. And there he can confidently say that dreams come true after many years of studying and travelling.

Analyzing departure of Hamma Skupynskyi abroad, it is necessary to say, that he is a vivid representative of the category "outflow of brains» and departure of high-qualified professionals, among which there were a lot of citizens of Ukraine of Jewish nationality to North America. He is the impersonation of those emigrants, who develop not the only economy by their work, but the culture and spirituality of the country of staying. Today, the best representatives of Ukrainian diaspora try to preserve and increase the national spirit of Ukrainian culture by means of art, following their predecessors abroad.

It is necessary to mark, that the problem of national identity is complicated enough and it stays sharper than in the majority of Western countries under conditions of development of modern Ukraine, as we «didn't have time» on the formation of a peculiar, clear and overall system of national identity. Staying in Ukraine in the composition of the USSR, the Soviet policy was directed on the suppression of national tendencies, connected with the creation of the national state, in relation to Ukraine and other Soviet republics. Promotion of the single nation of Soviet population leads to a certain «equation» of the rights and social status of the representatives of different nationally-ethnic groups. However, that fire of mutiny and protest was originated in the environment of the citizens of Ukraine, that gained distribution later among all «Soviet» nations and lead to a collapse of the Soviet Union [4]. The cooperation with foreign Ukrainians must be the priority of externally-political activity, providing positive international image, development of economic, cultural and other connections with foreign countries and providing economic, cultural and information presence in important geopolitical regions.

\section{תimepamypa}

1. Алексеева Л. История инакомыслия в СРСР / Людмила Алексеева. - 3-е изд., стер. - М. : Моск. Хельсинк. группа, 2012. - 384 с.

2. Бажан О. Процес десталінізації в Україні (II пол. 50-х - поч.60-х рр.) // 3 архівів ВУЧК - ГПУ - НКВД КГБ. - 1999. - № 1 / 2. - С. 469-480.

3. Баран В. Україна після Сталіна. Нарис історії 1953-1985 рр. - Львів: МП Свобода, 1992. - 124 с.

4. Герегова С.В. До питання дослідження мультикультурної спадщини: теоретичний та практичний аспекти (на матеріалах м. Чернівців) // Питання історії України. Зб. наук. пр. кафедри історії України Чернівецького нац. ун-ту імені Юрія Федьковича. - Чернівці: Технодрук, 2014. - Т. 17. - С. 163-164.

5. Данилюк Ю., Бажан О. Опозиційний рух в Україні (II пол. 50-х - 80-ті pp. XX ст.). - К.: Рідний край, 2000. $-616 \mathrm{c}$.

6. Доповідна записка секретаря ЦК Компартії України О.С. Капта про деякі питання посилення боротьби з антирадянською сіоністською пропагандою відвернення емігрантських настроїв серед окремої частини єврейського населення республіки від 28 вересня 1979 р. // Національні відносини в Україні у ХХ ст. Збірник документів і матеріалів. - К.: Наукова думка, 1994. - С. 431-436. 
102-114.

7. Конквест Р. Большой терор. - М., 1992. - 880 с.

8. Кульчицький С. Спроби реформ (1956-1964) // Український історичний журнал. - 1998. - № 2. - С.

9. Постанова ЦК КПУ про посилення цензури // Національні відносини в Україні у XX ст. Збірник документів і матеріалів. - К.: Наукова думка, 1994. - С. 364-367.

\title{
References
}

1. Alekseeva L. (2012). History of dissent in the USSR. Moskva : Mosk. Khel'synk. hruppa. [in Ukrainian].

2. Bazhan O. (1999). The process of de-Stalinization in Ukraine (second half of the 50's - early 60's. $Z$ arkhiviv VUCHK - HPU - NKVD - K HB - From the archives of the VUCHK - GPU - NKVD - KGB. [in Ukrainian].

3. Baran V. (1992). Ukraine after Stalin. Essay on the history of 1953-1985. L'viv: MP Svoboda. [in Ukrainian].

4. Herehova S.V. (2014). On the issue of research of the multicultural heritage: theoretical and practical aspects (on the materials of the city of Chernivtsi). Pytannya istoriyi Ukrayiny. Zb. nauk. pr. kafedry istoriyi Ukrayiny Chernivets'koho nats. universitetutu imeni Yuriya Fed'kovycha - Questions of the history of Ukraine. Zb sciences etc. Department of History of Ukraine Chernivtsi National University. un named after Yuri Fedkovich. Chernivtsi: Tekhnodruk. [in Ukrainian].

5. Danylyuk YU., Bazhan O. (2000). Opposition movement in Ukraine (second half of the 50's and 80's of the twentieth century. Kyjiv: Ridnyy kray. [in Ukrainian].

6. Statement by the Secretary of the Central Committee of the Communist Party of Ukraine O.S. The Covenant on Some Issues of Strengthening the Combating of Anti-Soviet Zionist Propaganda to Invert Emigrant Moods Among the Separate Part of the Jewish Population of the Republic of September 28, 1979. Natsional'ni vidnosyny $v$ Ukrayini $u$ KHKH st. Zbirnyk dokumentiv i materialiv - National Relations in Ukraine in the 20th Century. Collection of documents and materials. Kyjiv: Naukova dumka (1994). [in Ukrainian].

7. Konkvest R. (1992). Great Terror. Moskva. [in Ukrainian].

8. Kul'chyts'kyy S. (1998). Reform efforts (1956-1964). Ukrayins'kyy istorychnyy zhurnal - Ukrainian Historical Journal. [in Ukrainian].

9. Resolution of the Central Committee of the CPU on the strengthening of censorship. Natsional'ni vidnosyny $v$ Ukrayini u KHKH st. Zbirnyk dokumentiv i materialiv - National relations in Ukraine in the twentieth century. Collection of documents and materials. Kyjiv: Naukova dumka (1994). [in Ukrainian].

Стаття надійшла до редакції 15.07.2018 p.

УДК 746.3(477)

\author{
Варивончик Анастасія Віталіївна \\ кандидат мистецтвознавства, доцент, \\ доцент Київського університету \\ ім. Бориса Грінченка \\ ORCID: 0000-0002-4455-1109 \\ varivonchik@ukr.net
}

\section{ЕВОЛЮЦІЯ РОЗВИТКУ МАШИННОЇ ВИШИВКИ ТА СУЧАСНИХ ВИШИВАЛЬНИХ АВТОМАТІВ}

\begin{abstract}
Метою дослідження $є$ висвітлення обставин виникнення та відстеження історичного еволюційного унікального українського художнього промислу, відомого як вишивка, машинна вишивка та сучасні вишивальні автомати. Методологія дослідження ґрунтується на використанні спостережень мистецтвознавчого, історичного, та культурологічного аналізу. Наукова новизна полягає у розкритті фактів про вишивки, які у подальшому сприяли розвитку машинної вишивки, а згодом і розвитку індустрії вишивального виробництва з виникненням вишитих виробів завдяки сучасним вишивальним автоматам. Аналізуючи історичний розвиток художньої промисловості, яка працювала з виготовленням вишитих виробів можемо зробити такі висновки, що з 80-х років XX століття на території України деколи зустрічались вишиті вироби, які виконувались на вишивальних автоматах, частіше це були речі одягу, білизна тощо. Цей процес осучаснення і розвиток індустрії виробництв вишивального спрямування витісняють речі, що виконувались майстринями-вишивальницями багато років.
\end{abstract}

Ключові слова: традиції; художня промисловість; вишивальні машини; перфокарта; машина-автомат.

Варивончик Анастасия Виталиевна, кандидат искусствоведения, доцент, доцент кафедры изобразительного искусства Киевского университета имени Бориса Гринченка

Эволюция развития машинной вышивки и современных вышивальных автоматов

Целью исследования является освещение обстоятельств возникновения и отслеживания исторического эволюционного уникального украинского художественного промысла, известного как вышивка, машинная вышивка и современные вышивальные автоматы. Методология исследования основывается на использовании наблюдений искусствоведческого, исторического, и культурологического анализа. Научная новизна заключается в раскрытии фактов о вышивке, которые в последующем содействовали развитию машинной вышивки, а в дальнейшем и развитию индустрии вышивального производства, с возникновением вышитых изделий благодаря современным вышивальным автоматам. Анализируя историческое развитие художественной промышленности, которая работала с изготовлением вышитых изделий можем сделать такие выводы, что с 80-х годов XX века на

(C) Варивончик А. В., 2018 